\title{
The 50 year veterinary revolution in equine stud management
}

William R. (Twink) Allen

The Paul Mellon Laboratory of Equine Reproduction, 'Brunswick', Newmarket, UK
Editorial

\section{Introduction}

In 1960 the three major causes of infertility in Thoroughbreds, and indeed in most other large horse breeds, were failure to cycle normally during the breeding season due to persisting anoestrus or prolonged dioestrus, abortion of twins and uterine infection (endometritis). End of season pregnancy rates of $60-65 \%$ and live foaling rates of $\pm 50 \%$ were commonplace and generally accepted. The past half century has witnessed some dramatic advances in veterinary diagnostics and therapeutics on the studfarm such that, today, acyclicity has been vanquished, twinning has been eliminated, endometritis is held well in check and pregnancy rates and live foal rates of $92 \%$ and $83 \%$ respectively are the norm (Morris and Allen 2002, Allen et al 2007). But despite these marked improvements in overall fertility, other problems like early pregnancy failure, blocked oviducts, age-related endometrial degeneration (endometrosis), delayed uterine clearance, variation in stallion fertility and genetic-differences in the freezability of stallion semen, not to mention the persisting inefficiency of superovulation and the freezing of horse embryos, have come to the fore and still fox the minds and efforts of those engaged in theoretical and practical equine reproduction research. Worryingly, but at the same time an exciting scientific challenge, these present-day causes of reduced fertility are likely to remain much more intractable than those of the past 50 years which, in hindsight, fell like a "pack of cards" in the face of the veritable onslaught in advances in veterinary diagnostics and therapeutics which occurred during that period.

Professor Erich Klug was a major and much respected player in the equine reproduction revolution of past years and the following few words, written in his honour, attempt to summarise some of the veterinary advances which, in the autho$r^{\prime}$ s opinion, have had a positive and worthwhile impact on the efficiency of breeding horses.

\section{Diagnostic techniques}

The progesterone assay

During the early 1960s veterinary diagnosis of oestrous cyclicity and readiness for mating in the mare was based on a combination of teasing behaviour, rectal palpation of the ovaries and vaginoscopic examination of the cervix. This all worked remarkably well in mares that were cycling normally during the physiological breeding season (mid April to mid
October in the Northern hemisphere) but it had serious limitations in Thoroughbreds early in the arbitrary "covering season" (mid-February to mid-April) when two "physiological anomalies" of the mare's seasonality caused difficulties. First, the condition of "prolonged transition-phase anoestrus" or "prolonged Spring oestrus", when multiple medium-sized follicles develop and persist in the ovaries for some weeks as a result of inadequate exteroreceptive stimulation failing to release sufficient $\mathrm{LH}$ from the pituitary gland to effect maturation and ovulation of the dominant follicle. This caused frustrating delays to the time of first mating for many barren, and especially maiden, mares during the early part of the covering season in Thoroughbreds and it led frequently to "Spring oestrous" mares being covered repeatedly and needlessly, with the consequential waste of stallion mating potential at a time when his sperm production rate was seasonally lower than optimum. It also increased the chance of infective endometritis in the repeatedly mated mare that was physiologically unready for the bacterial challenges of coitus.

The second cyclical 'anomaly' in the mare was the common occurrence of "prolonged dioestrus". That is, abnormal prolongation of luteal lifespan beyond the normal $14-16$ days in the absence of pregnancy due, presumably, to insufficient release of endometrial prostaglandin (PGF2 $\alpha$ ) at the end of dioestrus, leading to a 60 - 85 day period of acyclicity akin to "pseudopregnancy" in the bitch (Stabenfeldt et al 1974, Allen et al 1974). This persisting luteal tissue, situated deep within the ovarian stroma was not palpable per rectum (Hughes et al 1975) so that mares which passed into prolonged dioestrus early in the breeding season or, more commonly, had passed through the previous winter in prolonged dioestrus, were usually considered to be still in seasonal anoestrus and therefore "given more time" to respond to the natural increases in daylength and ambient temperature of Spring.

The advent of simple, quantitative assays to measure progesterone concentrations in mare's blood, initially in the form of the rather tedious protein binding assay that required quantitative counting of tritium-type radioactive labels, but soon replaced by the modern, sensitive and rapid enzyme-linked immunoassay (ELISA), gave the required methodology to enable differential diagnosis of prolonged dioestrus from persisting anoestrus in the non-cycling maiden or barren mare early in the covering season, thereby enabling appropriate treatment to be given. The desk-top, kit-form, quantitative, amplified ELISA assay for progesterone (AELIA; Stanley et al. 1986, Allen and Sanderson 1987) available nowadays has 
also proved useful in other aspects of mare management. For example, to confirm or otherwise that ovulation has occurred within only $24 \mathrm{hrs}$ of its happening in cycling mares, to monitor maternal serum progesterone profiles during the first 100 days of gestation in mares considered to be 'at risk' of early pregnancy loss, and to assist in matching recipient mares with the donor animal in embryo transfer programmes. But perhaps its greatest potential advantage remains its use on large public studfarms to distinguish accurately as soon as they arrive on the property, genuine anoestrous mares from those that are already cycling and are in dioestrus, or are in prolonged dioestrus, so that each category can be treated appropriately and the delay to the onset of an ovulatory oestrus and mating minimised.

\section{Endometrial swabbing, cytology and biopsy}

Infective endometritis, of bacterial and occasionally fungal cause, and of venereal or non-venereal transmission, certainly "occupied the headlines" of practical equine reproduction during the 1960s and 1970s (Porchester 1965). Apparently healthy mares would "come up dirty" after covering (i.e. exhibit an inflamed cervix and show dried pus on the perineum and tail hairs) and the question that was asked repeatedly was what pathogen might be causing the problem and from whence had it originated? This led to the use of small, cotton wool-tipped disposable swabs attached to the end of an insemination-style catheter that could be passed through the relaxed, oestrous cervix via a duck-billed or tubular vaginal speculum and rubbed over the surface of the endometrium. In vitro culture of the swab on an appropriate medium enabled growth and identification of the causative bacterium or fungus which, in turn, enabled intrauterine treatment of the affected mare with the most appropriate antibiotic or antifungal agent (Ricketts 1981, 2011). Subsequently, the technique of endometrial cytology was added to the process whereby the endometrial swab, in addition to being cultured for bacterial growth, was smeared over the surface of a microscope slide. This was then stained to highlight the cell types present, with the presence of polymorphonuclear leucocytes (neutrophils) indicating the degree of inflammation in the endometrial tissue (Wingfield-Digby and Ricketts 1982).

Nowadays on most large, public Thoroughbred studfarms, the endometrium of all mares to be covered (maiden, barren and foaling) is swabbed early in oestrus in conjunction with cytology to ensure that the mare is not infected before she is covered. This is repeated in every subsequent oestrous period despite the fact that rigorous swabbing of the clitoral fossa and clitoral sinuses has been carried out on all mares at the beginning of the covering season to identify those that might be carrying venereal pathogens like Taylorella equigenitalis (CEMO), Klebsiella pneumonia or Pseudomonas aeruginosa (Simpson and Eaton-Evans 1978). Furthermore, such routine and repeated endometrial swabbing and cytology is undertaken despite the ability nowadays to visualise with great accuracy accumulations of pus, excess endometrial oedema or other signs of inflammation and infection in the uterus by means of ultrasound scanning (McKinnon and Carnevale 1982). Thus, despite the undoubted great value of endometrial swabbing and cytology when dealing with "difficult" mares which are prone to infective endometritis, there is a widespread feeling that the techniques are nowadays overapplied in large public Thoroughbred studfarms, more as palliatives and "veterinary moneyspinners" than as essential diagnostic tools.

Endometrial biopsy, whereby a small piece of endometrium is recovered by means of specially designed equine biopsy forceps with long handles and large jaws (Surgical Holdings, Southend-on-Sea, UK) for histological sectioning and assessment was highlighted as a useful diagnostic tool in the 1970s by the late Bob Kenney in Pennsylvania, USA (Kenney 1975, 1978) and Sidney Ricketts in Newmarket, England (Ricketts 1975). It has proved valuable to assess the degree of fibrous deposition and other age-related degenerative changes in the endometrium of older, sub-fertile mares (Kenney and Doig 1986). Nowadays collectively termed endometrosis (Allen 1993), these degenerative changes include erosions in the lumenal epithelium, untoward collections of leucocytes in the sub-epithelial stroma and generalised fibrous deposition in the stroma causing blockage of the lymph drainage channels to form lymphatic lacunae in the stroma and lymph-filled endometrial cysts which protrude into the uterine lumen. In addition, concentric deposition of fibrous tissue around the basal portions of the endometrial glands leads to the production of so-called "gland nests" in which the lumenae are occluded and the glands become distended with accumulated exocrine secretion (Kenney 1978). The resulting reduction in endometrial gland function and output diminishes the amount of histotroph available to the young unimplanted conceptus and, indeed, to the growing fetus throughout gestation. This, together with the reduction in size, complexity and fetomaternal contact in the interdigitating microcotyledons as a result of fibrous deposition in the endometrial stroma, causes varying degrees of nutritional depravation of the fetus leading to abortion or the birth of small, undersized foals (Rossdale and Silver 1982, Bracher et al 1996).

\section{Ultrasound scanning}

Dr Eric Palmer at the INRA Station de Physiologie de la Reproductione in Nouzilly, France first introduced the linear array ultrasound scanner to the horsebreeding world when he "borrowed" his human obstetrician father's scanner to " have a play" in the rectum of some experimental Pony mares (Palmer and Driancourt 1980). The result was a defining moment for equine reproduction worldwide. The large ovaries of the mare with their especially large $(3-5 \mathrm{~cm}$ diameter) fluid-filled follicles and the relatively short, straight horns and body of the equine uterus suspended in the abdomen immediately beneath the rectum and containing a fluid-filled conceptus which remained unattached to the endometrium and doesn't even begin to elongate until as late as 40 days after ovulation (Allen and Wilsher 2009), made the mare the 'perfect animal' for transrectal ultrasonography. Thus, at a stroke, the mystique of the "expert rectal palpating veterinary clinician" of previous years was swept away and the significant echographic features of the growing and ovulating follicle and the developing corpus luteum were plainly visible for all to see, not to mention the "magic" of viewing the unattached spherical conceptus from as early as day 10 or 11 after ovulation and monitoring development, movement and viability of the 
embryo proper from around day 20. It was a real revelation and, put simply, ultrasound scanning revolutionised the science and practice of equine reproduction.

Extensive clinical trials on significant numbers of experimental Pony (Chevalier and Palmer 1982) and commercial Thoroughbred (Simpson et al 1982) mares quickly followed Palmer's original observations and these established the accuracy and limitations of the technique in the context of commercial studfarm practice. $\bigcirc$. J. Ginther at Wisconsin University in America then undertook a series of studies using the scanner to monitor the physical development of the horse conceptus and map its movement around the uterus up to day 16 after ovulation and its "fixation" thereafter (Ginther 1985, 1986). The original scanner employed in the studies by Chevalier and Palmer (1982) and Simpson et al (1982) was a cumbersome machine designed for use in human obstetrics and gynaecology wards but its large $3.5 \mathrm{MHz}$ transducer was useable in the mare's rectum simply because the lead connecting it to the imaging apparatus emerged from one end, rather than the dorsal surface, of the probe. Previously, in the days of rectal palpation alone, it had been common practice in large studfarms for the veterinary clinician to move from stable to stable to examine each mare per vaginum or per rectum around the stable door. This proved highly impractical for scanning due both to the difficulty of moving the scanner between stables and the greatly reduced clarity of the scanning image when viewing it in bright sunlight. Accordingly, and to the satisfaction of the veterinary personnel involved, stud managers were forced to erect stocks inside barns at strategic sites on the studfarm and the mares to be examined were henceforth brought to this location. Scanning had really 'come to stay' in the day-to-day practice of equine stud veterinary medicine and management and nowadays the much smaller and compact scanner which provides an amazingly clear, high definition image is "standard kit" for any equine veterinary practitioner engaged in horse breeding.

The scanner has had a significant impact upon a number of equine stud management practices, especially in the Thoroughbred. Its ability to follow development and maturation of the pre-ovulatory follicle and monitor the degree of oedema in the endometrium (McKinnon and Carnevale 1992) and thereby accurately pinpoint the most advantageous time for mating has engendered a "single covering per mare per oestrus" policy on large Thoroughbred studfarms. This, in turn, has enabled stallion owners to treble or more the number of mares 'booked' to popular stallions, from a norm of 40-45 in the 1960s to >140 nowadays. This increase, combined with the common practise of "shuttling" stallions between the northern and southern hemispheres, means that some horses now cover 300 or more mares in a calendar year. This is an incredible number when considering that the stallion, if "living in the wild", would impregnate a harem of only some 5-15 mares annually and it is surprising that relatively few Thoroughbred stallions show definite signs of reduced fertility as a result of overuse (Bosh et al 2009, Allen and Wilsher 2011 ).

Three other uses of trans-rectal ultrasonography have been of particular benefit to Thoroughbred breeding. First, the ability to accurately diagnose singleton and multiple pregnancies in mares as early as 12 days after ovulation thereby allowing minimal handling thereafter of mares carrying a singleton conceptus and appropriate treatment of those carrying twins or triplets; namely, crushing one conceptus manually per rectum between days 13 and 16 after ovulation when their continued mobility in the uterine lumen allows easy manipulative separation of the two conceptuses prior to crushing. This combination of early accurate diagnosis and a $>93 \%$ success rate when performing twin reduction has virtually eliminated twinning as the previously most significant cause of pregnancy failure in Thoroughbred mares (Pascoe 1983) and scanning has revealed two other interesting aspects of the twinning phenomenon. Namely, the frequent disparity in the size and chronological age of twin conceptuses (3-5 days) resulting from the combination of the longevity of stallion spermatozoa in the mare's reproductive tract and the occurrence of a second, unrealised ovulation early in dioestrus (Hughes et al, 1975), and the high rate (70-80\%) of spontaneous death and resorption of one of twin conceptuses developing in the same uterine horn occasioned by the misalignment of one conceptus within the uterine lumen so that its absorptive choriovitelline membrane becomes abutted against its co-twin instead of the endometrium rendering it unable to imbibe sufficient histotroph to survive.

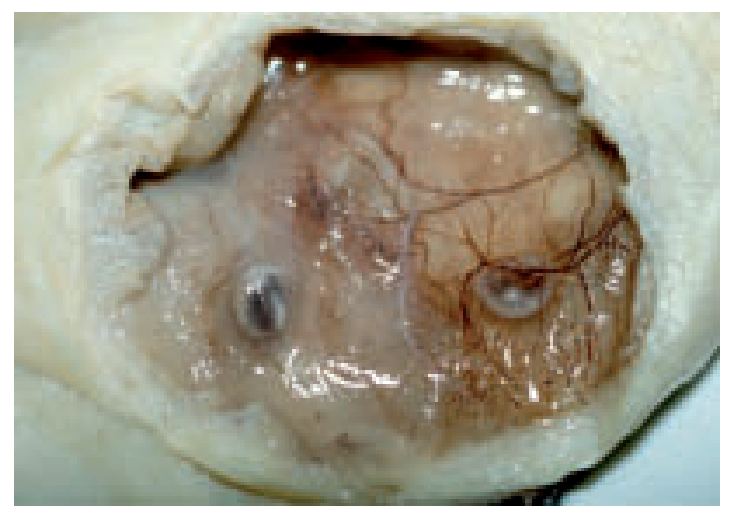

Fig. 1 Unicornate twin horse conceptuses in situ at 26 days of gestation. One conceptus is viable and healthy but the other has died of starvation because its highly absorptive choriovitelline membrane is abutted up against its co-twin instead of the histotrophsecreting endometrium.

Two other uses of the scanner in horse breeding are worthy of mention. First, its ability to accurately diagnose non-pregnancy in mated mares as early as 12 - 14 days after ovulation, therefore providing the veterinary clinician with sufficient confidence to administer a prostaglandin F analogue to bring the mare back into oestrus for a further mating very much sooner than was possible in pre-scanning days. Second, to visualise untoward accumulations of post-mating/insemination fluid or pus in the uterine lumen, thereby enabling treatment with an ecbolic drug like oxytocin to cause its evacuation (Allen 1991). This function of uterine fluid diagnosis and clearance has proved particularly valuable in aged, maiden, Sporthorse mares in which their tight and fibrosed cervix fails to relax sufficiently during oestrus to enable accumulated uterine fluid to dissipate naturally. Also, in aged multiparous Thoroughbred mares exhibiting myometrial atonicity and ventral dependence of the uterus in the abdominal cavity due to repeated pregnancy-associated stretching of the broad ligaments. 


\section{Videoendoscopy}

A second visualising technique that has revolutionised equine veterinary medicine, both in the upper respiratory and gastrointestinal tracts at the front end of the horse in the racing stable, and in the reproductive tract at the rear end of the mare on the studfarm is strobed-light videoendoscopy. It is a relatively simple procedure to pass the flexible endoscope through the tight, dioestrous cervix of the lightly sedated mare restrained in stocks and, after infusing filtered air to expand the uterine lumen, move through it to view the endometrium and any pathological structures associated with it in great detail and with amazing clarity (Figure 2; Bracher and Allen 1992). And a further advantage is for multiple people simultaneously to be able to view and discuss the remarkably clear real-time picture portrayed on the video screen.

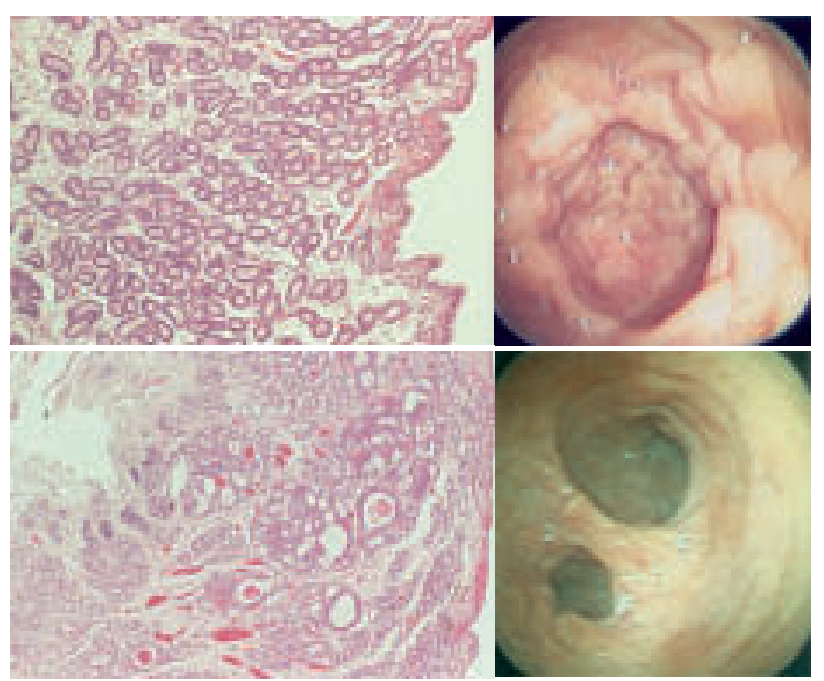

Fig. 2 The gross appearance of the endometrium as viewed by videoendoscope and the histological appearance of a biopsy of that endometrium, in a healthy young mare (upper panels) and an aged, subfertile mare suffering endometriosis (lower panels).

In the two decades since the introduction of intrauterine videoendoscopy to equine stud medicine the technique has found two major applications. First, as mentioned, to survey the degree and extent of any structural, aged-related or chemically induced pathological changes in the endometrium or cervix (Bracher et al 1992) and, by means of either an NDYAG laser fibre passed through the working channel of the endoscope or by the passage of an electrocautery loop and/or endometrial biopsy forceps alongside the endoscope to simply ablate such space-occupying pathological lesions as lymph-filled endometrial cysts (Bracher et al 1994) which, when clustered together at the base of one or both uterine horns may prevent the establishment of pregnancy by physically impeding the normal intrauterine mobility of the conceptus between days 6 and 16 after ovulation (Ginther 1985, McDowell et al 1985), or may impede the choriovitelline membrane from imbibing endometrial gland histotroph during days 18-30 (Allen and Wilsher 2009). Other foreign objects like as detached endometrial swab tips or glass marbles (inserted stupidly to suppress oestrous cyclicity in competing mares) can be removed and translumenal fibrous adhesions resulting from foaling injuries or the unthinking infusion of irritant solutions such as antiseptic iodine derivatives can also be ablated (Bracher et al 1994).

The second use of the videoendoscope in equine stud medicine is to infuse a small volume (50-80 microlitres) of diluted stallion semen containing a very small number of spermatozoa $\left(1-10 \times 10^{6}\right)$ directly onto the ipsilateral uterotubal papilla via a slender polystyrene catheter passed through the working channel of the endoscope (Morris et al 2000). This low dose insemination method has particular application to the use of sex-selected semen where relatively low numbers of spermatozoa (i.e. $20-40 \times 10^{6}$ ) are "sortable" within a 2 hour time period that does not unduly diminish the fertilising capability of the sex-sorted spermatozoa (Lindsey et al 2002). Nowadays it is also being used to split the dose of deep-frozen stallion semen recommended by stallion owners for conventional insemination. This arises from the commercially unfair resolve of many stallion owners to sell their frozen semen on the basis of the dose or fixed number of straws, regardless of the quality and fertility of the semen. It would be more appropriate that they charge on a "per pregnancy established" basis.

\section{Rigid laparoscopy}

Although this method of visualising biological structures and tissues was employed originally in the horse to examine the cartilaginous surfaces of longbone joints and remove detached pieces of cartilage from damaged joints (Mclllwraith 2002), the technique has been employed to good effect in recent years in the equine abdomen, both to visualise and diagnose medical conditions such as intestinal volvulus, constriction or strangulation (Fischer et al 1986) and to carry out "keyhole surgical procedures" like ovariectomy and removal of granulosa cell tumours, all performed via trochar puncture of the flank musculature under local anaesthesia (Hanson and Galuppa 1998).

Another beneficial use of flank laparoscopy in the mare is the application of a prostaglandin E2 (PGE2) gel to the external surface of the oviducts in aged, infertile mares to dislodge suspected blockages. In the mare, the combination of the large volume of protein-rich follicular fluid released at ovulation $(50-80 \mathrm{ml})$ and the anatomical oddity that ovulation can only occur through the ovulation fossa means that appreciable quantities of follicular fluid enter the oviduct via the dilated oviducal fimbria overlying the fossa. Here the trapped fluid becomes inspissated to form coils of gelatinous, fibrinoid material into which leucocytes and fibroblasts migrate (Onuma and Ohnami 1975). With increasing age and repeated sterile oestrous cycles these oviducal coils may accumulate in the narrow ampullary-isthmus junction of the oviduct and thereby block the passage of an embryo towards the uterus should fertilisation occur (Liv et al 1991). When both oviducts become blocked in this way the affected mare appears not to conceive despite being covered or inseminated by fertile stallions in repeated, ovulatory oestrous cycles and in the absence of any discernible pathology of the uterus or cervix. Based upon the original demonstration by Weber and his colleagues at the School of Veterinary Science in Moscow, Idaho, USA that surgical implantation of minipumps releasing low doses of PGE2 onto the mesovarium of mares on day 4 after ovulation will hasten entry of the embryo into the uterus by $24 \mathrm{~h}$ 
(Weber et al 1991a), and that the morula-stage oviducal embryo releases considerable quantities of PGE2 when cultured in vitro (Weber et al. 1991b), the author's laboratory similarly hastened oviduct transport of the embryo by applying a single, pharmacological dose of PGE2 in triacin gel onto the external surface of the ipsilateral oviduct on day 4 after ovulation via a rigid laparoscope passed through the lateral flank of the mare (Robinson et al. 1999). This then led to a clinical trial in which a total of 15 Thoroughbred and Arabian mares with inexplicable infertility were treated by the same laparoscopic application of PGE2 gel onto both oviducts, often on day 4 or 5 after a previous mating (Allen et al. 2006). All 15 treated mares conceived within 1-3 mated oestrous cycles after application of the gel and the method has since entered the armoury of equine stud veterinary clinicians for use in mares which fail to conceive repeatedly for no discernable reason.

\section{Therapeutic Advances}

In parallel with the diagnostic advances of the past half century there has occurred an equal revolution in useful new therapeutic agents available to the equine stud veterinary practitioner. These may be loosely grouped into prostaglandins, progestagens, gonadotrophins and ecbolic agents.

\section{Prostaglandins}

Prior to the discovery in the late 1960s that prostaglandin F2 $\alpha$ (PGF2 $\alpha$ ) secreted by the endometrium is the luteolytic agent that controls the oestrous cycle in all the large domestic animal species (see McCracken et al 1973 for review), and the parallel synthesis of natural PGF2 $\alpha$ by Upiohn Limited in the USA and a number of potent PGF analogues by $\mathrm{ICl}$ Pharmaceuticals in the UK, failure to show regular oestrous cycles during the arbitrary covering season (mid-February mid-July) was by far the commonest cause of infertility in Thoroughbred mares (Allen et al 1974, Stabenfeldt et al 1974). As mentioned previously, in the absence of the rapid progesterone assay and transrectal ultrasound scanning this lack of cyclicity was mistakenly assumed to be persistence of winter or lactation-related anoestrus and treatment was limited to "washing out" the uterus by infusing a large volume of warmed physiological saline (Neely et al 1974, Arthur 1975). This treatment worked well in a few mares purely, it was discovered subsequently, by the irritation of non-buffered saline on the endometrium stimulating the release of its stored PGF2 $\alpha$.

The discovery during the early 1970s that a small dose of either natural PGF2 $\alpha$ (Douglas and Ginther 1972) or any of three ICI Pharmaceuticals PGF2 $\alpha$ analogues (Allen and Rowson 1973, Allen and Rossdale 1973, Allen et al 1974), either infused into the uterus or injected intramuscularly, would rapidly induce luteolysis of the cycling or persistent corpus luteum followed by a return to fertile oestrus in 2-4 days was a considerable revelation. It led the following year to a largescale clinical trial on Thoroughbred studfarms in the Newmarket area of England in which some 300 non-cycling maiden, barren and lactating mares which showed an elevated serum progesterone concentration were treated with a single dose of an $\mathrm{ICl}$ Pharmaceuticals prostaglandin $\mathrm{F}$ analogue.
The results were dramatic and almost all of the treated mares showed oestrous behaviour within 3 days went on to ovulate and conceive normally. Nowadays, a wide range of prostaglandin $\mathrm{F}$ analogues are used routinely in equine stud veterinary practice, either to induce luteolysis in mares showing prolonged dioestrus or to shorten dioestrus in mares that were not covered in the previous oestrus. They are also used commonly to synchronise oestrus and ovulation in groups of mares for the purposes of batch insemination with fresh or frozen semen and for embryo transfer (Palmer and Jousset 1975), to induce abortion of unwanted pregnancies, as an ecbolic agent to stimulate prolonged myometrial contractions in mares suffering retention of uterine fluid after natural mating or insemination with frozen-thawed semen, and to hasten ovulation in oestrous mares (Savage and Liptrap 1987).

\section{Progestagens}

With the advent of prostaglandin $\mathrm{F}$ analogues to shorten normal dioestrus and cure prolonged dioestrus in the early 1970s, soon afterwards came progestagen withdrawal therapy to shorten transitional phase shallow anoestrus, suppress and overcome prolonged Spring oestrus and synergise with prostaglandin to synchronise oestrus and ovulation in groups of cycling mares for batch insemination or embryo transfer. R. G. (Bob) Loy working in Lexington, Kentucky, was early on this scene and he gave daily i.m. injections of $150-200 \mathrm{mg}$ progesterone-in-oil to anoestrous mares for 10-12 days. This was usually followed by the onset of a fertile oestrus 3-5 days after the last of the daily injections, more so if the mare had been under artificial lighting for some weeks beforehand (Loy and Swan 1966, Loy et al 1975). Subsequently, Loy added $10 \mathrm{mg}$ oestradiol benzoate to each daily injection of progesterone which caused a more marked suppression of ovarian activity during the 10 days of progesterone administration and a more strongly expressed oestrus and precise ovulation after the end of the treatment (Loy et al 1982). The impracticality of daily injections and the tendency for muscle soreness in the treated mares was soon overcome by the development of the orally active progestagen, allyl trenbolone (Regumate; Intervet Laboratories, Cambridge, UK) in the early 1980s. Here, the active ingredient could similarly be administered to anoestrous mares for a 10-12 day period, either orally in the feed or as a low volume drench (Allen et al. 1980, Webel and Squires 1982), or impregnated into a polystyrene intravaginal sponge (Palmer 1979). Either way, progestagen-withdrawal therapy worked well in around $85 \%$ of shallow anoestrous or prolonged Spring oestrus mares but was much less effective in deep winter anoestrous mares and in mares that had been in lactation-related anoestrus for some weeks before the commencement of treatment (Allen et al. 1980).

Allyl trenbolone has seen widescale application use to suppress unwanted oestrous behaviour in competing Sporthorse fillies and to supplement serum progesterone levels in pregnant mares. It is nowadays administered routinely daily to large numbers of pregnant mares during at least the first half of gestation despite the complete lack of evidence that any deficiency of endogenous progesterone production exists in the treated animals, and in the face of the compelling evidence produced by the late Professor Cliff Irvine and his team in 
Christchurch, New Zealand that early pregnancy failure in mares is not associated with low serum progesterone concentrations (Irvine et al 1990). Such indiscriminate use of the hormone in pregnant mares is a sad reflection of the pressure on equine stud veterinary clinicians to "treat anyway" and therefore avoid the accusative approbrium of disgruntled owners for their inaction should any mare abort spontaneously, almost certainly for another unrelated reason.

Finally, progestagen therapy in mares has received another boost recently with the clever development of a range of injectable, slow-release, depot formulations of progesterone and allyl trenbolone which exhibit a remarkably precise cessation of release of the active ingredient in the treated animal (BioPharm Laboratories, Lexington, Kentucky, USA). Thus, the same therapeutic effects can be achieved by a single intramuscular injection of a low volume $(2-5 \mathrm{ml})$ of material, given to both anoestrous mares requiring progestagen withdrawal to simulate endogenous $\mathrm{LH}$ release, and to competing fillies to suppress pituitary gonadotrophin output leading to ovarian quiescence. It is a major and clever step forwards.

\section{Gonadotrophins and gonadotrophin releasing hormone (GnRH)}

A significant drawback of any progesterone or progestagen withdrawal therapy to induce cyclicity in seasonally anoestrous mares is the minimum 16-18 day interval from the start of treatment to the occurrence of ovulation, occasioned by the necessity of 10 days of progesterone suppression to achieve the desired rebound of $\mathrm{LH}$ release upon cessation of progesterone/progestagen administration. It is more logical, if possible, to administer from the outset either the gonadotrophins required to stimulate follicular development and ovulation or to simulate the mare's own pituitary gland to release appropriate amounts of $\mathrm{FSH}$ and $\mathrm{LH}$ to achieve the same result.

Dr Eric Palmer and his colleagues at Nouzilly in France first demonstrated the merits of supplying exogenous gonadotrophins to mares when he administered twice-daily injections of a partially purified extract of horse pituitary glands (CEG) both to anoestrous mares to induce oestrus and ovulation and to cycling mares with a maturing follicle to induce ovulation (Duchamp et al 1987). Both uses of the preparation proved advantageous, the only drawback being the necessity for twice-daily injections over 6-8 days in the anoestrous animals and the difficulty and cost of obtaining the pituitary extract. Furthermore, such use of exogenous pituitary gonadotrophins was soon superseded by the advent of a range of natural and analogue preparations of $\mathrm{GnRH}$, the small decapeptide secreted in a pulsatile fashion in the hypothalamus which stimulates release of FSH and/or LH from the pituitary gland depending upon the steroid hormone background prevailing in the animal at any particular time. Thus, gonadotrophin administration was soon steered away from seasonally anoestrous mares and concentrated instead towards the induction of superovulation in valuable donor mares in embryo transfer programmes. Partially purified extracts of, initially porcine and subsequently equine, pituitary glands were administered twice or thrice daily to mid-dioestrous donor mares for 6-8 days to induce the development of multiple follicles in their ovaries. They were then given a single dose of human Chorionic Gonadotrophin (hCG) to attempt to ovulate the multiple mature follicles. Sadly, such gonadotrophin therapy has proved to be relatively impractical and of limited value, simply because of the unusual anatomy of the equine ovary. A number of independent studies using a variety of gonadotrophin preparations over the past 20 years reported varying degrees of "superovulation" in the treated mares, as diagnosed by ultrasonographic detection of multiple luteal structures in their ovaries, but all have showed a considerable disparity between "supposed ovulation rate" and the number of embryos recovered when flushing the mare's uterus 7 or 8 days later. As illustrated in Figure 3, the
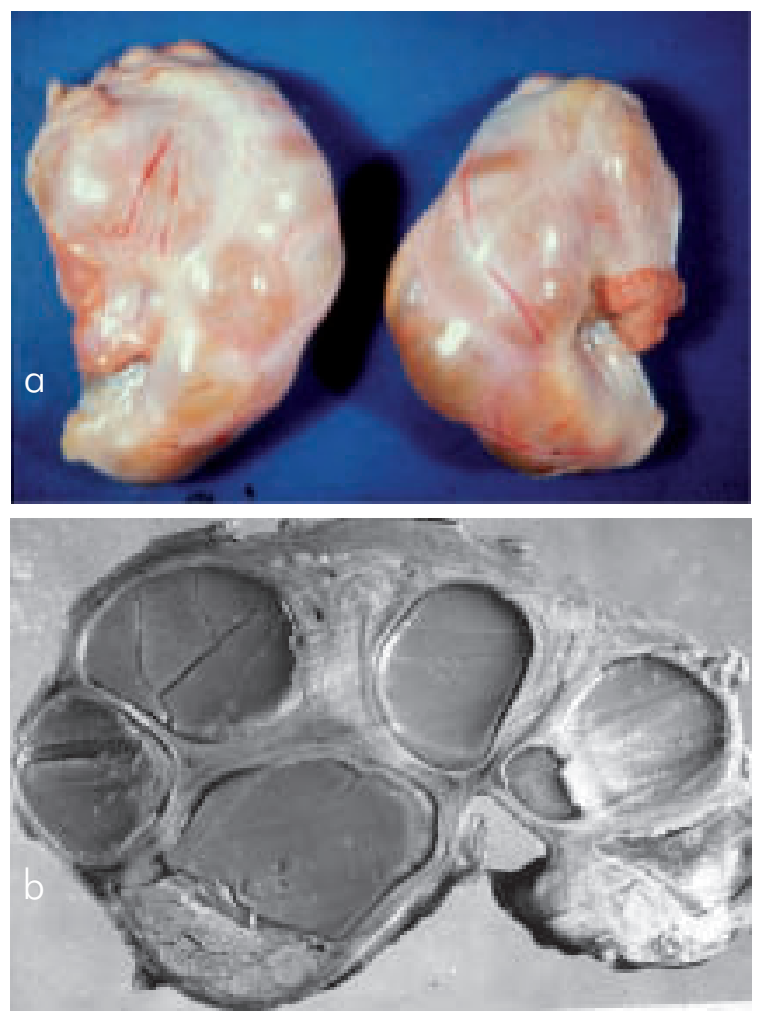

Fig 3a The ovaries of a mare in early oestrus showing the tough, fibrous tunica albuginea surrounding the ovary except for the dent-like ovulation fossa on one border. b A fixed mare ovary bisected to show the crowding effect of multiple follicles. Those adjacent to the dent-like ovulation fossa can ovulate through it while those at the periphery cannot track through the ovarian stroma to reach the fossa.

limitation in equids that ovulation can only occur through the ovulation fossa due to the impenetrability of the tough, fibrous tunica albuginea which surrounds the ovary means that multiple large follicles must compete with one another when tracking through the ovarian stroma to gain access to the fossa. Clearly, those that develop near the fossa ovulate, whereas those further from it can't do so and they can only luteinise without actually rupturing. Thus, anatomy defeats chemistry in this instance and even with the advent in recent years of highly purified preparations of both equine FSH and equine LH synthesised by recombinant gene technology (Meyers-Brown et al 2010), follicular crowding within the confines of the tunica albuginea still limits the true ovulation rate, and hence embryo recovery rate, in stimulated mares.

As mentioned, potent GnRH analogues quickly replaced pituitary gonadotrophin preparations as the cheapest and most 
efficient way of driving follicular development and ovulation in the anoestrous mare. Early on the author and his colleagues showed how subcutaneous insertion of a low-dose, slow-release implant impregnated with the potent $\mathrm{GnRH}$ analogue, buserelin, designed to downregulate pituitary gonadotrophin release in human cancer patients, would induce follicular development and ovulation in 8-10 days in a high proportion of mares in deep winter anoestrous or prolonged lactation-related anoestrous (Allen et al 1987). The high cost of the implant seriously limited its use in equine stud medicine, however, and it was soon superseded by a much shorter acting and cheaper implant (Ovuplant, Peptech Industries, Sydney, Australia) releasing another $\mathrm{GnRH}$ analogue, deslorelin acetate, which could induce ovulation in $38-42 \mathrm{~h}$ in a high proportion (i.e. $>90 \%$ ) of oestrous mares exhibiting a dominant follicle of $\geq 35 \mathrm{~mm}$ (Johnson et al 2002). This basic function of hastening ovulation in normal, cycling mares to limit matings to one per oestrous period had, for the previous 50 years since the pioneering studies of Bob Loy and John Hughes in Lexington, Kentucky (Loy and Hughes 1966), been performed by a single i.v. or s.c. injection of $1500-3000$ i.u. hCG; (Chorulon; Intervet Laboratories, Cambridge, UK). Still used widely and successfully today, hCG, as a foreign protein of human origin, has the single potential disadvantage of stimulating harmful antibody production in mares to which it is administered repeatedly in the same breeding season or to which it is given by i.m. rather than i.v. injection. Such antibodies when they do develop may delay or completely suppress ovulation rather than stimulating it (Duchamp et al 1987, Roser et al 1979). For this reason, Ovuplant initially gained widescale use throughout the entire equine reproduction world until it too was found to have a disadvantageous side effect. Namely, continued release of GnRH from the subcutaneous implant beyond the period required to induce ovulation of the mature follicle in the oestrous mare could sometimes downregulate pituitary function and thereby delay a return to oestrus and ovulation in those mares that had failed to conceive to mating in the earlier Ovuplant-treated oestrus (Johnson et al 2002). This problem was largely overcome by inserting the implant into the vaginal mucosa just inside the vulval lips to facilitate its easy location and removal after the treated mare had ovulated. However, the impracticality and added expense of this further veterinary manipulation greatly reduced the use of the implant method of ovulation induction and Ovuplant was taken off the market in many countries. Happily, the more recent development of deslorelin as an intramuscular injection to induce ovulation in cycling mares (VetPharm, Lexington, Kentucky, USA) has provided a good alternative. A very high (>90\%) proportion of treated mares ovulate within $40-42 \mathrm{~h}$ after administration and they show higher conception rates than similar mares induced to ovulate with hCG (Kölling and Allen 2006). Thus, at last a safe, effective and reasonably priced hormone preparation is available to reliably induce ovulation in oestrous mares which is devoid of unwanted side effects.

\section{Oxytocin}

One other useful form of therapy in equine stud medicine, which has witnessed a dramatic upsurge in recent years in direct relation to the advent of transrectal ultrasonography, is the intravenous administration of the ecbolic drug, oxytocin, to oestrous and post-ovulation mares which show excessive or prolonged accumulations of intrauterine fluid to stimulate strong myometrial contractions to evacuate the unwanted fluid via the cervix. Untoward intrauterine fluid accumulation of this nature appears to have three main causes. First, in ageing, multiparous mares, slackening of the broad ligaments which suspend the uterus within the abdomen combined with myometrial atony causes oestrous and inflammatory fluids to depend into "parity-induced" pouches at the base of each uterine horn. Second, in ageing nulliparous Sporthorse mares the long and particularly muscular and unstretched cervix is unable to relax sufficiently during oestrus to allow spontaneous expulsion of oestrous uterine fluid. Third, excessive uterine fluid produced in mares inseminated with frozen-thawed stallion semen as a consequence of endometrial inflammation induced by irritant breakdown products of spermatozoa damaged during the freezing and thawing processes (Allen 1991). In pre-scanning days such fluid accumulation was often not recognised by the attending veterinary clinician and it undoubtedly caused very early embryonic death in a significant proportion of mated or inseminated mares, thereby contributing to lowered pregnancy rates (Sanderson and Allen 1987). Nowadays, in contrast, fluid accumulation before or after mating or insemination is looked for and easily diagnosed by the scanner so that affected mares can be treated successfully by repeated intravenous injections of 10-20iu oxytocin.

Two other aspects of ecbolic therapy in oestrous mares are worthy of brief comment. First, the ultrasonographic recognition and oxytocin-induced evacuation of accumulations of "normal" (i.e. non-infective) uterine fluid has significantly reduced the previously excessive and often unnecessary infusion of irritant antibiotic preparations into the uteri of noninfected mares. Second, the increasingly common veterinary approach of infusing large quantities of buffered saline or other physiological solutions into mares' uteri to "wash them out" when ultrasonography shows them to already have an existing accumulation of their own endogenous fluid. Undoubtedly a sensible approach if echogenicity of the accumulated fluid indicates the mare is suffering an infective endometritis but questionable in the author's opinion if her medical history and the scanning image indicates "mechanical" accumulation of otherwise normal, non-infected fluid. Why load more fluid into an already "stressed" uterus, with the attendant risk of actually inducing infective endometritis, when all that is required is simple, repeated ecbolic administration to rid the uterus of its endogenous material while the cervix is still sufficiently relaxed to allow its passage?

\section{Conclusions}

The foregoing is no more than an amble down a 40 -year-old personal "memory lane" of the fascinating field of equine reproduction research and application. The author counts himself fortunate to have travelled that particular road, often in the very pleasant and stimulating company of Professor Erich Klug, and to have had the satisfaction of witnessing the development and application to good effect of the abovementioned and many other new diagnostic and therapeutic methods to the enjoyable, and occasionally profitable, business of breeding horses. It is to be hoped that the road is still 
very much open to further new, and as yet undreamed of, advances in the coming years. Our new-found knowledge of the equine genome (Swinburne et al 2006) must surely point the way to exciting progress in breeding efficiency, but only if horse owners and breeders can be convinced of, and will utilise to good effect, the benefits of the information gained.

\section{Acknowledgements}

Grateful thanks are due to Dr Sandra Wilsher and Miss Jennifer Levitt for valuable assistance in the preparation of this manuscript.

Keywords: Mare, oestrous cycle, pregnancy loss, anoestrus, prolonged dioestrus, prostaglandins, progestagens, ultrasound scanning, progesterone assay, laparoscopy, reproduction, horse

Schlüsselwörter: Stute, Zyklus, Anöstrus, verlängerter Diöstrus, Prostaglandin, Progsteron, Sonographie, Assay, Laparoskopie, Reproduktion, Pferd

\section{References}

Allen W. E. (1991) Investigations into the use of exogenous oxytocin for promoting uterine drainage in mares susceptible to endometritis. Vet. Rec. 128 593-594

Allen W. R. (1993) Proceedings of the John Hughes International Workshop on Equine Endometritis. Equine vet. J. 25 184-193

Allen W. R. and Rossdale P. D. (1973) A preliminary study upon the use of prostaglandins for inducing oestrus in non-cycling Thoroughbred mares. Equine vet. J. 5 137-140

Allen W. R. and Rowson L. E. A. (1973) Control of the mare's oestrous cycle with prostaglandins. J. Reprod. Fert. 33 539-543

Allen W. R. and Sanderson M. W. (1987) The value of a rapid progesterone assay (AELIA) in equine stud veterinary medicine and management. Proc. 9th Bain-Fallon Memorial Lectures, pp. 75 82. AEVA, Sydney

Allen W. R. and Wilsher S. (2009) A review of implantation and early pregnancy in the mare. Placenta $301005-1015$

Allen W. R. and Wilsher S. (2011) The influence of mare numbers and ejaculation frequency on the fertility of Thoroughbred stallions. In: Rossdale and Partners Stallion Sub-fertility Course. Ed S. Ricketts, pp 1-3 Whorl Publishing Ltd, Newmarket UK

Allen W. R., Brown L., Wright M. and Wilsher S. (2007) Reproductive efficiency of Flatrace and National Hunt Thoroughbred mares and stallions in England Equine vet. J. 39 438-445

Allen W. R., Sanderson M. W., Greenwood R. E. S., Ellis D. R., Crowhurst J. S., Simpson D. J. and Rossdale P. D. (1987) Induction of ovulation in anoestrous mares with a slow-release implant of a $\mathrm{GnRH}$ analogue (ICI 118 630) J. Reprod. Fert. Suppl. 35 469-478

Allen W. R., Stewart F., Cooper M. J., Crowhurst R. C., Simpson D. J., McEnery R. J., Greenwood R. E. S., Rossdale P. D. and Ricketts S. $W$. (1974) Further studies on the use of synthetic prostaglandin analogues for inducing luteolysis in mares. Equine vet. J. $631-35$

Allen W. R., Urwin V. E., Simpson D. J., Greenwood R. E. S., Crowhurst R. C., Ellis D. R., Ricketts S. W., Hunt M. D. N. and WingfieldDigby N. J. (1980) Preliminary studies on the use of an oral progestagen to induce oestrus and ovulation in seasonally anoestrous Thoroughbred mares. Equine Vet. J. 12 141-145

Allen W. R., Wilsher S., Morris .L, Crowhurst J. S., Hillyer M. H. and Neal H. N. (2006) Laparoscopic application of PGE2 to re-establish oviducal patency and fertility in infertile mares: a preliminary study Equine vet. J. 38 454-459
Arthur G. H. (1975) Influence of intrauterine saline infusion upon the oestrous cycle of the mare. J. Reprod. Fert. Suppl. 23 231-234

Bosh K. A., Powell D., Shelton B. and Zent W. (2009) Reproductive performance measures among Thoroughbred mares in central Kentucky, during the 2004 mating season. Equine vet. J. 41 883-888

Bracher V. and Allen W. R. (1992) Videoendoscopic examination of the mare's uterus. I. Findings in normal fertile mares. Equine vet. J. 24 274-278

Bracher V., Mathias S. and Allen W. R. (1992) Videoendoscopic examination of the mare's uterus. II. Findings in sub-fertile mares. Equine vet. J. 24 279-284

Bracher V., Mathias S. and Allen W. R. (1996) Influence of chronic degenerative endometritis (endometrosis) on placental development in the mare. Equine vet. J. 28 180-188

Bracher V., Stone R. and Allen W. R. (1994) Transendoscopic $\mathrm{Nd}$ :YAG laser surgery for treatment of intrauterine adhesions in 4 mares. Equine vet. Educ. 6, 22-26

Chevalier F. and Palmer E. (1982) Ultrasonic echography in the mare. J. Reprod. Fert. Suppl. 32 423-430

Douglas R. H. and Ginther O. J. (1972) Effect of prostaglandin F2 on length of dioestrus in mares. Prostaglandins 2 265-268

Duchamp G., Bour B., Combarnous Y. and Palmer E. (1987) Alternative solutions to hCG induction of ovulation in the mare. J. Reprod. Fert. Suppl. 35 221-228

Fischer A. T. Jr, Lloyd K. C., Carlson G. P. and Madigan J. E. (1986) Diagnostic laparoscopy in the horse. J. Am. Vet. Med. Assoc. 189 289-292

Ginther O. J. (1985) Dynamic physical interactions between the equine embryo and uterus. Equine. vet. J. Suppl. 3 41-47

Ginther O. J. (1986) Ultrasonic Imaging and Reproductive Events in the Mare. Equiservices, Cross Plains, Wisconsin

Hanson C. A. and Galuppa L. D. (1998) Bilateral laparoscopic ovariectomy in standing mares. Proc. Am. Assoc. Equine Pract. 44 300-303

Hughes J. P., Stabenfeldt G. H. and Evans J. W. (1975) The oestrous cycle of the mare. J. Reprod. Fert. Suppl. 23 161-166

Irvine C. H. G., Sutton P., Turner J. E. and Mennick P. E. (1990) Changes in plasma progesterone concentrations from days 17 to 42 of gestation in mares maintaining or losing their pregnancies. Equine vet. J. 22 104-106

Johnson C. A., McMeen S. L. and Thompson D. L. (2002) Effect of multiple $\mathrm{GnRH}$ analogue (deslorelin acetate) implants on cyclic mares. Theriogenology 58, 469-471 (Abstr)

Kenney R. M. (1975) Prognostic value of endometrial biopsy of the mare. J. Reprod. Fert. Suppl. 23 347-348

Kenney R. M. (1978) Cyclic and pathological changes of the mare endometrium as detected by biopsy, with a note on early embryonic death. J. Am. vet. med. Assoc. 172 241-262

Kenney R. M. and Doig P. A. (1986) Equine endometrial biopsy. In: Current therapy in Theriogenology 2 Ed DA Morrow. pp723-729

Kölling M. and Allen W. R. (2006) Ovulation induction for embryo transfer: hCG versus GnRH analogue. Havemeyer Foundation Monograph Series No. 18. pp. 54-55 (Abstr).

Lindsey A. C., Morris L. H.-A., Allen W. R., Schenk J. L., Squires E. L. and Bruemmer J. E. (2002) Hysteroscopic insemination of mares with low numbers of nonsorted or flow sorted spermatozoa. Equine. vet. J. 34 128-132

Liu I. K. M., Lantz K. C., Schlafke M. A., Bowers J. M. and Enders A. C. (1991) Clinical observations of oviductal masses in the mare. Proc. Am. Assoc. equine Pract. 32, 41-45

Loy R. G., Evans M. J., Pemstein R. and Taylor T. B. (1982) Effect of injected ovarian steroids on reproductive patterns and performance in post-partum mares. J. Reprod. Fert. Suppl. 32 205-212

Loy R. G. and Hughes J. P. (1966) The effects of human Chorionic Gonadotrophin on ovulation, length of oestrus and fertility in the mare. Cornell Vet. 56, 41-50

Loy R. G. and Swan S. M. (1966) Effects of exogenous progestagens on reproductive phenomena in mares. J. Anim. Sci. 25 821-826

Loy R. G., Hughes J. P., Richards W. P. C. and Swan S. M. (1975) Effects of progesterone on reproductive function in mares after parturition. J. Reprod. Fert. Suppl. 23 291-295 
McCracken J. A., Baird D. T., Carlson J. C., Goding J. R. and Barcikowski B. (1973) The role of prostaglandins in luteal regression. J. Reprod. Fert. Suppl. 18 133-142

McDowell K. J., Sharp D. C., Peck L. S. and Cheves L. L. (1985) Effect of restricted conceptus mobility on maternal recognition of pregnancy in mares. Equine vet. J Suppl. 3 23-24

Mclllwraith C. W. (2002) Arthroscopy, an update. In: Clinical techniques in equine practice. Ed. C. W. Mclllwraith pp200-220. WB Saunders, Philadelphia

McKinnon A. O. and Carnevale F. M. (1992) Reproductive examination of the mare: Ultrasonography. In: Equine Reproduction. Eds. A. O. McKinnnon and J. L. Voss. Chapter 24 pp211-220. Lee and Febiger, Philadelphia

Meyer-Brown G., Bidstrup L., Famula T., Colgin M. and Roser J. F. (2010) Increasing embryo recovery from superovulating mares through the use of recombinant equine follicle stimulating hormone and recombinant equine luteinising hormone. Anim. Reprod. Sci. 1215 56-57 (Abstr)

Morris L. H.-A. and Allen W. R. (2002) Reproductive efficiency of intensively managed Thoroughbred mares in Newmarket. Equine vet. J. 34 51-60.

Morris L. H.-A., Hunter R. H. F. and Allen W. R. (2000) Hysterscopic insemination of small numbers of spermatozoa at the uterotubal junction of preovulatory mares. J. Reprod. Fert. 118 95-100.

Neely D. P., Hughes J. P., Stabenfeldt G. H. and Evans J. W. (1974) The influence of intrauterine saline infusion on luteal function and cyclic ovarian activity in the mare. Equine vet. J. 6 150-157

Onuma H. and Ohnami Y. (1975) Retention of tubal eggs in mares. J. Reprod. Fert. Suppl. 23 507-511

Palmer E. (1979) Reproductive management of mares without detection of oestrus. J. Reprod. Fert. Suppl. 27 263-270

Palmer E. and Driancourt M. A. (1980) Use of ultrasonic echography in equine gynecology. Theriogenology 13 203-216

Palmer E. and Jousset B. (1975) Synchronisation of oestrus in mares with a prostaglandin analogue and hCG. J. Reprod. Fert. Suppl. 23, 269-274

Pascoe R. R. (1983) Methods for the treatment of twin pregnancy in the mare. Equine vet. J. 15 40-42

Porchester Lord (1965) Uterine infections in mares. Vet. Rec. 77, 110-111

Ricketts S. W. (1975) Endometrial biopsy as a guide to endometrial pathology in the mare. J. Reprod. Fert. Suppl. 23, 34 1-345

Ricketts S. W. (1981) Bacteriological examinations of the mare's cervix: techniques and interpretation of results. Vet. Rec. 108, 46

Ricketts S. W. (2011) Microbiological culture techniques and interpretation. In Equine Reproduction, 2nd Edition. Ed. A. O. McKinnon E. L. Squires W. E. Vaala and D. D. Varner. Volume 2, Chapter 208, 1963-1978. Wiley Blackwell, lowa

Robinson S. J., Neal H. and Allen W. R. (1999) Modulation of oviducal transport in the mare by local application of prostaglandin E2. J. Reprod. Fert. Suppl. 56 587-592

Roser J. F., Kiefer B. L., Evans J. W., Neely D. P. and Pacheco C. P. (1979) The development of antibodies to human chorionic gonadotrophin following its repeated injection in the cyclic mare. J. Reprod. Fert. Suppl. 27 173-179
Rossdale P. D. and Silver M. (1982) The concept of readiness for birth. J. Reprod. Fert. Suppl. 32 507-510

Sanderson M. W. and Allen W. R. (1987) Reproductive efficiency of Thoroughbred mares in the U.K. Proc. 9th Bain-Fallon Memorial Lectures, pp. 30-41. AEVA, Sydney

Savage N. C. and Liptrap R. M. (1987) Induction of ovulation in cyclic mares by the administration of a synthetic prostaglandin, fenprostalene, during oestrus. J. Reprod. Fert. Suppl. 35 239-243

Simpson D. J. and Eaton-Evans W. E. (1978) Isolation of the CEM organism from the clitoris of the mare. Vet. Rec. 10219

Simpson D. J., Greenwood R. E. S., Ricketts S. W., Rossdale P. D., Sanderson M. and Allen W. R. (1982) Use of ultrasound echography for early diagnosis of single and twin pregnancy in the mare. J. Reprod. Fert. Suppl. 32 431-439

Stabenfeldt G. H., Hughes J. P., Evans J. W. and Neely D. P. (1974) Spontaneous prolongation of luteal activity in the mare. Equine vet. J. 6 158-163

Stanley C. J., Paris F., Webb A. E., Heap R. B., Ellis S. T., Hamon M., Worsfold A. and Booth J. M. (1986) Use of a new and rapid milk progesterone assay to monitor reproductive activity in the cow. Vet. Rec. 118 664-667

Swinburne J. E., Boursnell M., Hill G., Pettitt L., Allen W. R., Chowdhary B., Hasegawa T., Kurosawa M., Leeb T., Mashima S., Mickelson J. R., Raudsepp T., Tozaki T. and Binns M. (2006) Single linkage group per chromosome genetic linkage map for the horse, based on two three-generation, full-sibling, crossbred horse reference families. Genomics 87 1-29

Webel S. K. and Squires E. L. (1982) Control of the oestrous cycle in mares with altrenogest. J. Reprod. Fert. Suppl. 32 193-198

Weber J. A., Freeman D. A., Vanderwall D. K. and Woods G. L. (1991a) Prostaglandin hastens oviductal transport of equine embryos. Biol. Reprod. 45 544-546

Weber J. A., Freeman D. A., Vanderwall D. K. and Woods G. L. (1991b) Prostaglandin E2 secretion by oviductal transport stage equine embryos. Biol. Reprod. 45 540-543

Wingfield Digby N. J. and Ricketts S. W. (1982), Results of concurrent bacteriological and cytological examinations of the endometrium of mares in routine studfarm practice 1978-81. J. Reprod. Fert. Suppl. 32, 181-185.

Prof. William R. (Twink) Allan

The Paul Mellon Laboratory of Equine Reproduction

'Brunswick'

18 Woodditton Road

Newmarket

Suffolk CB8 9BJ UK

pml@btinternet.com 